Swarthmore College

Works

5-1-1996

\title{
Tolerance: Should We Approve Of It, Put Up With It, Or Tolerate It?
}

\author{
Barry Schwartz \\ Swarthmore College, bschwar1@swarthmore.edu
}

Follow this and additional works at: https://works.swarthmore.edu/fac-psychology

Part of the Psychology Commons

Let us know how access to these works benefits you

\section{Recommended Citation}

Barry Schwartz. (1996). "Tolerance: Should We Approve Of It, Put Up With It, Or Tolerate It?". Academe. Volume 82, Issue 3. 24-28. DOI: 10.2307/40251476

https://works.swarthmore.edu/fac-psychology/180

This work is brought to you for free by Swarthmore College Libraries' Works. It has been accepted for inclusion in Psychology Faculty Works by an authorized administrator of Works. For more information, please contact myworks@swarthmore.edu. 


\section{Tolerance: Should We Approve of It, Put up with It, or Tolerate It?}

Author(s): Barry Schwartz

Source: Academe, Vol. 82, No. 3 (May - Jun., 1996), pp. 24-28

Published by: American Association of University Professors

Stable URL: http://www.jstor.org/stable/40251476

Accessed: 25-09-2017 18:43 UTC

JSTOR is a not-for-profit service that helps scholars, researchers, and students discover, use, and build upon a wide range of content in a trusted digital archive. We use information technology and tools to increase productivity and facilitate new forms of scholarship. For more information about JSTOR, please contact support@jstor.org.

Your use of the JSTOR archive indicates your acceptance of the Terms \& Conditions of Use, available at http://about.jstor.org/terms 


\section{T O L E R A N C E:}

\section{Should We}

\section{Approve of It,}

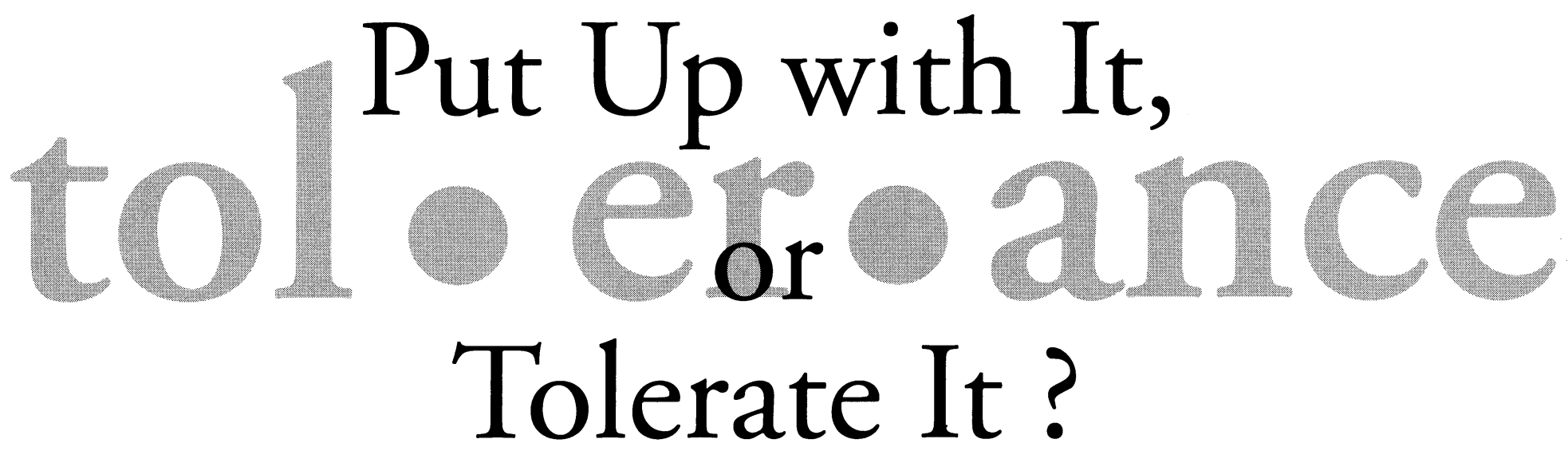

BY BARRY SCHWARTZ

1

$S$ GOOD LIBERALS IN A LIBERAL SOCIETYand especially as citizens of that bastion of liberalism, the academy - we value tolerance. We try to instill tolerance in our students as we teach them to respect differences among people and among groups. We try to practice it ourselves. And we reserve our strongest condemnation for individuals or institutions that are intolerant. We deeply believe that tolerance is the one virtue of character on which a liberal, pluralistic society most depends. Liberal society can survive dishonesty. It can survive disloyalty. It can survive (and may even encourage) selfishness. But it can't survive intolerance. Indeed, as philosopher John Rawls has suggested, liberal society may even have invented tolerance as a practical feature of social life. Before pluralistic, liberal societies demonstrated that the successful practice of tolerance was possible, it was "natural to believe, as the centuries-long practice of intolerance appeared to confirm, that social unity and concord requires agreement on a general and comprehensive religious, philosophical, or moral doctrine." We now know better, and we can be proud of our collective tolerance. It may be liberalism's finest achievement.

Before we get too proud, however, it may be a good idea to take

Barry Schwartz is the Dorwin P. Cartwright Professor of Social Theory and Social Action in the psychology department at Swarthmore College. a closer look at what tolerance actually is. The dictionary tells us that to tolerate is "to allow what is not actually approved." So when we say we tolerate something, we are implying a negative judgment about it. We are saying, in effect, that we wish it wasn't there, but for one reason or another we aren't prepared to do anything to stop it. This understanding of tolerance may cast it in a somewhat less favorable light, because at the same time that we are allowing something to occur, we are being judgmental-we are being disapproving. Is this what we mean to say when we say that we tolerate different lifestyles, different family arrangements, and different religious beliefs and practices-that they aren't as good as ours, but they aren't so bad that we should expend our energy to stop them?

I don't think so. I think that most of the time what we have in mind when we speak of tolerance is something closer to "acceptance," or even "celebration." Acceptance implies approval, and celebration implies enthusiastic approval. This is closer to what we have in mind when we teach our students to be tolerant. "They're just as good as we are, only different" is what we want our students to learn.

Perhaps to say that tolerance implies either disapproval on the one hand, or acceptance on the other, is an overstatement. Perhaps tolerance implies little more than indifference (I say "little more" than indifference because when one is truly indifferent about something, the issue of tolerance doesn't even arise; in 

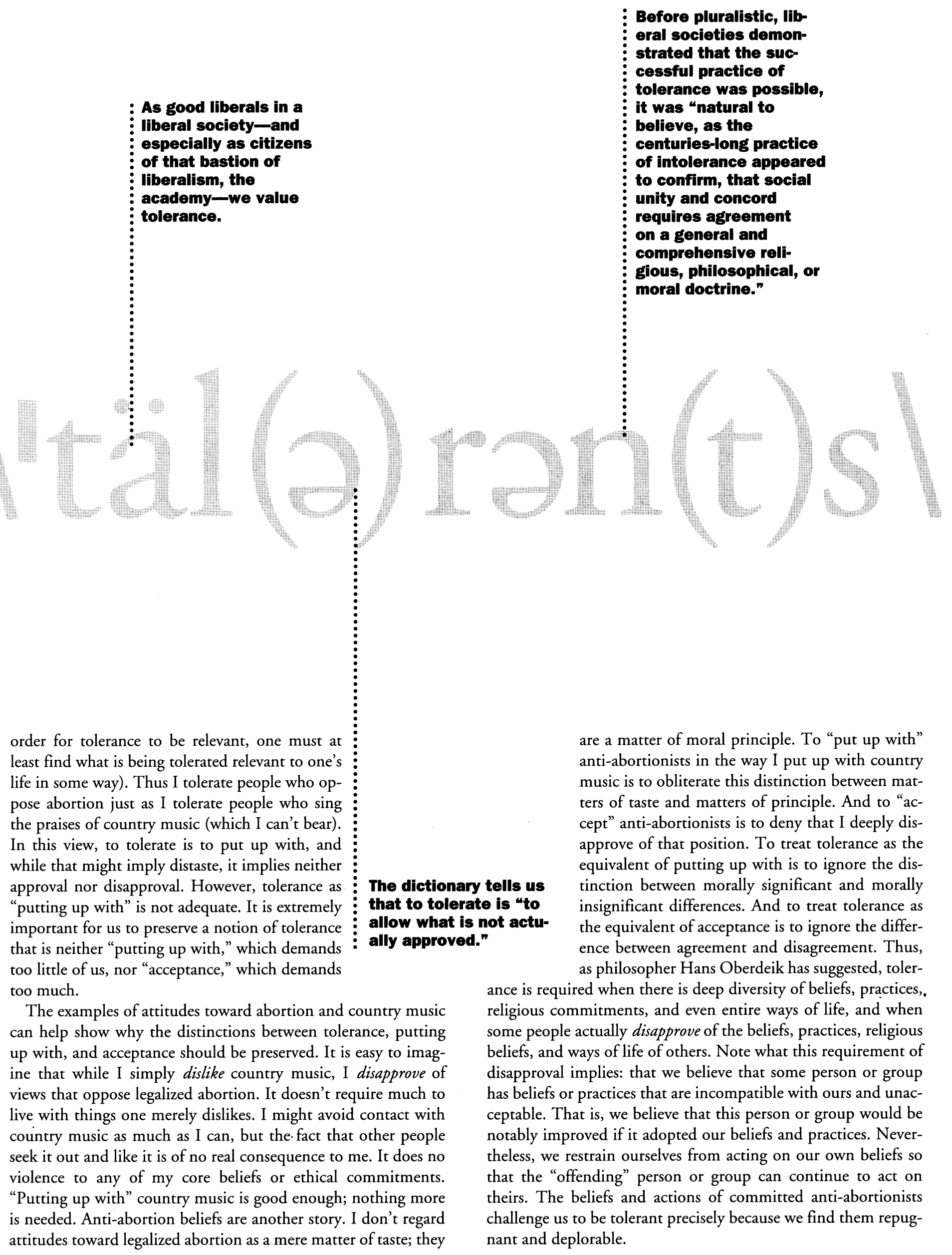

are a matter of moral principle. To "put up with" anti-abortionists in the way I put up with country music is to obliterate this distinction between matters of taste and matters of principle. And to "accept" anti-abortionists is to deny that I deeply disapprove of that position. To treat tolerance as the equivalent of putting up with is to ignore the distinction between morally significant and morally insignificant differences. And to treat tolerance as the equivalent of acceptance is to ignore the difference between agreement and disagreement. Thus, as philosopher Hans Oberdeik has suggested, tolerance is required when there is deep diversity of beliefs, practices, religious commitments, and even entire ways of life, and when some people actually disapprove of the beliefs, practices, religious beliefs, and ways of life of others. Note what this requirement of disapproval implies: that we believe that some person or group has beliefs or practices that are incompatible with ours and unacceptable. That is, we believe that this person or group would be notably improved if it adopted our beliefs and practices. Nevertheless, we restrain ourselves from acting on our own beliefs so that the "offending" person or group can continue to act on theirs. The beliefs and actions of committed anti-abortionists challenge us to be tolerant precisely because we find them repugnant and deplorable. 
This characterization of tolerance makes it seem challenging enough that one might ask if it's worth it. Why tolerate beliefs, practices, and ways of life that one judges to be morally unacceptable? Why not make it as hard as possible for anti-abortionists to exhort others to share their views, especially when they show so little tolerance themselves for people whose views they find objectionable?

Today, when any discussion of values is treated with suspicion, it is tempting to answer this question by appealing to relativism or skepticism. The reason to tolerate the beliefs and practices of others is that there is no right or wrong (relativism), or if there is one, there is no way to know what it is (skepticism). If people actually believed this, they would have to tolerate anti-abortionists because they would either have no grounds at all for criticizing that position; or their grounds would be nothing more than personal preference ("I think abortion should be legal, don't you?"). A skeptical defense of tolerance is essentially a negative defense; people tolerate others only because they have no grounds for being intolerant. Among its problems, it is hard to know how from a skeptical point of view tolerance itself could be justified as a worthy stance to take toward other people.

A more compelling and positive defense of tolerance is available, deriving from the writings of John Stuart Mill in the last century and amplified by Joseph Raz in the current one. Mill justifies tolerance by appealing to the view that people should have autonomy to be the authors of their own lives. It is good and important that people should find their own way to the best way of life. Tolerance encourages people to find their own way, though it obviously leàves open the real possibility that they will fail. The importance of autonomy must be elaborated by two additional points. First, there are many distinctive, worthwhile, yet incompatible ways to live. These alternatives are much more than mere matters of taste; they are morally significant and engender deep commitments, and even sacrifices, on the part of their practitioners. And second, no person is an island. Acknowledging that people are autonomous does not mean that they can live apart from a meaningful community. Thus, to enable individuals to be the authors of their own lives requires that we tolerate groups they can join whose beliefs and practices they find compelling. If we believe that people should be the authors of their own lives, that people depend on membership in moral communities to live fully human lives, and that incompatible, worthwhile ways of life are possible, then it is our duty to be tolerant. Thus, we must acknowledge that a commitment to oppose legal abortion that stems from, say, certain religious views, is a morally significant and worthwhile commitment, even if it includes beliefs and practices, like opposition to legal abortion, that we find unacceptable.

To summarize the argument thus far, to tolerate something is neither to accept it nor merely to put up with it. People put up with things when they really don't care much about them, and they accept things when they agree with them. In contrast, when people tolerate things, they permit them to occur even though they do care about them and they disagree. Thus, people can accept, or perhaps celebrate, that (some) anti-abortionists are deeply committed to the doctrine of universal love, and people can put up with their observance of Christmas as a national holiday. But people must tolerate their stance on abortion. And tolerance is good and important not because of skepticism about human values, but because of a positive conception we have of how people should live and what they need to flourish. If we are going to be serious about a commitment to autonomy and social connectedness, we have no choice but to disagree with things and to tolerate them.

\section{Tolerance and Critical Engagement}

$\mathrm{P}$ EOPLE CAN ONLY TOLERATE THINGS OF WHICH THEY disapprove. Indeed, "disapprove" may be too mild. People may be disgusted by and disdainful of practices they tolerate. They may despise them. Yet, they tolerate them, because they acknowledge and respect the importance of these practices to the way of life of the people who engage in them, and because they respect that way of life, as a morally informed way of life, even if it's not informed by the morality they favor.

So if people tolerate a practice or a way of life, what then do they do about it? They surely can't embrace it, for to embrace it would be to accept it, and they don't accept it. But they also can't ignore it, for to ignore something that is of central importance to someone else is demeaning and disrespectful. What's left is to criticize it. To criticize a practice or a way of life is simultaneously to acknowledge its importance and its unacceptability. To do any less is to fail to take the practice and the people who engage in it seriously. The only way to show respect for a way of life of which we disapprove is through active critical engagement. But note what kind of society this "respect" produces: an interactive, conflictive, "judgmental" society. And note the problems it creates for those who strive to be tolerant and for those who are being tolerated. The tolerated face being told that their way of life is defective in a significant way. This is not an easy thing to have to hear. And the tolerant are forced to support something with which they strongly disagree, out of respect for its importance to other people who are struggling to be the authors of their own lives.

To appreciate how hard this is, think about some concrete examples. Suppose you think that a monogamous relationship organized around the bearing and nurturing of children should be a part of a fulfilled human life. Tolerance now demands that you confront and criticize your friends who are single or childless by choice. Suppose you think that while homosexuality is not an 
abomination, it isn't important enough in the grand scheme of things to become the central part of a person's identity. Tolerance now demands that you confront your gay friends and tell them, at the very least, that they are making too much of their sexual orientation. Tolerance similarly demands that you tell your black friends that their separatism is destructive and their Afrocentric view of history is a fiction (if that's what you believe), that you tell your Catholic friends that their position on abortion is wrong, and that you tell orthodox Jews that their treatment of women is abhorrent.

This kind of critical engagement is not what ordinarily comes to mind when people think about tolerance; people typically think that tolerance demands that they not be judgmental. I am suggesting that the opposite is true. This understanding of tolerance hardly conjures up an image of a world that is peaceful and harmonious. If this is what tolerance demands, who wants it?

One answer to this question that has become increasingly clear is that minority groups don't want it. It may once have been good enough for these groups to be tolerated. But nowadays, tolerance has become intolerable. What these groups now demand is not tolerance but acceptance-celebration. "Who are you to 'tolerate' me? Who are you to say that my way of life is inferior to yours? Who are you to judge?" We can hear these sentences even as we imagine suggesting to someone whose practices we tolerate that he or she should be living differently. Fifty years ago, perhaps, when the possibilities for Jews in America were tolerance (not tolerance really, but putting up with) or intolerance, tolerance was plenty good enough. "You don't have to approve of us or even respect us. Just leave us alone, let us use a little corner of your field, and we'll stay out of your way. Even if you don't let us into your prestigious universities and professional schools, as long as you don't bother us, we'll make do." But now? Imagine the anger that would rise up if someone were to tell you that your dietary practices were silly superstitions, your God was vengeful, and your refusal to accept Jesus Christ would damn you to hell. Could you tolerate being tolerated in this way?

So minority groups now demand approval, but that isn't what they get. What they get instead is putting up with. This is not always easy to spot. Behaviorally, these groups get silence, which can easily be interpreted as (tacit) approval. And perhaps sometimes silence is approval, but I think most of the time it is merely politeness, a thin veneer that covers over deep disagreements about how life should be lived-a veneer that slips away when members of the group in question aren't around. This silent putting up with is unacceptable because it is dishonest, disrespectful, and patronizing. It is hard to get used to the idea that the way to show respect for someone's way of life is not by being silent, but by telling that person why you find it unacceptable.
Nevertheless, I think that open critical engagement is what respect for difference demands.

Putting up with masquerading as approval is the real problem created by the atmosphere of political correctness that dominates many of our social institutions - especially universities-these days. Political correctness produces silence in the face of disagreement. Because the stance of the institution may be approval rather than tolerance, the silence of the members who comprise the institution is often interpreted as approval as well. But it isn't, at least not always, and while all may appear harmonious on the surface, deep disagreements simmer beneath it. And efforts by institutions to curb the way members of different groups talk to and about one another only further encourage the silence. There is a double irony in this institutionally enforced silence. First, the norms and rules that are promulgated by these institutions are usually promulgated in the name of "respect for difference," but what they actually produce is the disrespect that putting up with implies. Second, the institutions that promulgate respect for difference characteristically also encourage their members to seek a multicultural education - to come to know deeply, and thus appreciate, the way different people live. But in an atmosphere of enforced silence, multicultural education seems pointless. If students were taught that the way to show respect is through critical engagement, and that critical engagement requires knowing other ways of life deeply, they might actually approach multicultural education with some enthusiasm. And who knows? Perhaps as people learned about another way of life, with the objective of criticizing it, their growing understanding might turn tolerance into acceptance or celebration.

If the way to show respect for people with whom one disagrees is by expressing that disagreement, why not urge society in a direction that dispenses with politeness and encourages truly tolerant people to say what's on their minds? What's the harm? The harm, alas, is substantial. As philosopher Charles Taylor has pointed out, human beings need to establish identity, an understanding of who they are-of their fundamental characteristics as human beings. And this identity will almost always include their membership in groups-in moral communities. But what this need for identity requires is recognition by others. And so "a person or a group of people can suffer real damage, real distortion, if the people or society around them mirror back to them a confining, or demeaning, or contemptible picture of themselves...misrecognition shows not just a lack of due respect. It can inflict a grievous wound, saddling its victims with a crippling self-hatred. Due recognition is not just a courtesy we owe people. It is a vital human need." Because of this, the demands of tolerance put people squarely on the horns of a dilemma. To be silent-to put up with while pretending to approve-is to fail to give "due recognition." But to criticize can 
present people a "demeaning, contemptible picture of themselves." What are we to do?

While it would be nice to find some way to avoid this kind of conflictive social engagement, perhaps by replacing tolerance with approval, it is simply not possible. It is simply not possible for me to approve of committed anti-abortionists demonstrating outside abortion clinics. And it is simply not possible for me to approve of Jews who won't allow women to see, let alone read from the Torah. In a pluralistic society and a pluralistic age, deep differences in the moral commitments of different groups of people are. unavoidable. Unless we are prepared to abandon pluralism, we are stuck with tolerance.

\section{Tolerance and Putting Up With}

HIS BRINGS US BACK TO THE DISTINCTION BE-
tween tolerance and putting up with. How does this dis-
tinction matter? Often, it's just a matter of attitude. Tolerance implies an appreciation of the value of autonomy and of the importance of some practice to that autonomy. Putting up with does neither. But it isn't always just a matter of attitude. For example, parents put up with their adolescent child's desire to be a heavy metal rock musician by not getting in the way. But they tolerate it by helping it to happen. A college puts up with black separatists on campus by leaving them alone and punishing those who harass them. It tolerates them by giving them a place to meet as an organization, by providing special services in the dean's office, by giving them a budget for group activities, and by developing courses that speak to their particular concerns. Neither parents with regard to their child's musical preferences nor colleges with regard to black separatists need to approve of the practices to devote resources to them. All they need to do is acknowledge the importance of the practices to people who are pursuing a way of life that is worthy of respect.

Why on earth, in the name of tolerance, should we feel an obligation not just to restrain ourselves from interfering with a practice of which we disapprove, but to act in a way that facilitates it? The answer is based not on principles but on practicality. In a world of dramatically unequal power and control of material resources, doing nothing to get in the way is no better than putting up with; it is simply not good enough. Groups that lack resources will not be able to sustain themselves and their practices without our help. If we think that what these groups want to do is not really morally significant-to be put up with, that is, rather than tolerated-then we owe them nothing. And, of course, if we think what these groups want to do is morally significant but intolerable, then we surely owe them nothing, except perhaps every effort on our part to get in their way. But if we think that the aims of the group are morally significant and tolerable, then in the service of autonomy, authorship, and recognition, we should help them do what they want to do at the same time that we try to convince them that they shouldn't want to do it.

The commitment to tolerate less powerful groups requires active support, not passive putting up with. Is it really possible for anyone actually to do this? I don't know. What I do know is that in a world of unequal power, claims of tolerance on the part of the powerful who do nothing to assist the powerless whom they tolerate have a distinctly disingenuous ring-so much so that the claims may themselves be intolerable. 